\title{
Lifestyle Peculiarities of Riga Basic School and University Students
}

Juris Porozovs Dr. biol.

University of Latvia, Latvia juris.porozovs@lu.lv

\begin{abstract}
Lifestyle is an important factor which influence student's health, way of life and study results. Students usually have many home works, high mental load and sometimes - emotional strain. These circumstances influence students' lifestyle. At the same time lifestyle should be healthy and active, enough physical activities are necessary in order to maintain good physical fitness and health level. The aim of the study was to compare lifestyle peculiarities of basic school students and higher educational institution students. The electronic survey of Riga $2^{\text {nd }}$ Gymnasium $9^{\text {th }}$ grade basic school students and University of Latvia 1st course pedagogical programmes students was carried out. Altogether 130 students were questioned. The results of the research showed that university students spend more time on a computer than basic school students. They spend more time on a computer on activities connected with studies, but the time which students spend on a computer with activities not connected with studies do not greatly differ between both group students. The time which students spend doing study home works in general does not significantly differ between student groups, but some basic school students spend much time more than 20 hours during week - by doing study home works. The physical activity level of basic school students is higher than the physical activity level of university students. For many university students' physical activity level is very low, it is recommended to improve it. The time which students spend watching TV, reading literature and dealing with music is not greatly different between basic school students and university students. The time, which students spend during sleep, is longer for university students in comparison with basic school students. For many basic school students, it is too short.
\end{abstract}

Keywords: school education, lifestyle, students, physical activities, work with computer.

\section{Introduction}

Lifestyle is one of the most important factors that influence students' health level, study outcomes, motivation to learn and quality of life. Unhealthy lifestyle can lead to obesity, health disturbances, emotional problems, sleep and behavioural disturbances and promote the formation of social problems. The most common health problems among young people are linked with wrong diet, lack of physical activities, use of addiction causing substances and wrong sexual behaviour.

In many countries of the world obesity of children', and adults is rapidly growing. Investigations have shown that high amount of time spent on academic-related activities, excessive homework, inadequate sleep, physical inactivity and high screen viewing time are major contributors to high paediatric obesity (Ren et al., 2017). Long duration of stressful home works is a potential obesity causing factor in children (Michaud et al., 2015). The majority of students did not meet physical activity recommendations. Scientists have come to the conclusion that immediate action, and efforts should be made worldwide to increase levels of physical activity among schoolchildren (Guthold et al., 2010).

Students might be one of the groups among the population, who experience a deep emotional strain. Emotional strain affects an individual's health condition negatively. Apart from studies, students do part time jobs to earn money, which increase their mental load. Psychological load is closely linked with the emotional strain. Appropriate physical activities and healthy lifestyle favours to keep up students' health and work performance as well. Students, who participate in sports and physical activities, collaborate in household activities, do not smoke and do not use addictive drugs, do not consume stimulant drinks, have fit and healthy meals, spend less time per day on the computer, interactive games and TV, go out with friends moderately, usually have good quality sleep, sleep more, watch videos, study, read, and do not use the computer before going to sleep, have better health and they also achieve better school performance (Pestana, Duarte, Coutinho, 2015).

The lifestyle and interests of students are influenced by region where student lives. Results of research have shown that adolescents living in rural areas are less exposed to the sedentary behaviour, they chose more active leisure, and have higher level of physical activity (Regis et al., 2016). The results of other investigations have shown that in general adolescents who live in towns are more satisfied with life than adolescents who live in urban areas (Viera et al., 2015). Previous investigations by Latvian scientists have 
shown that rural school students in general more often feel the lack of time and overload than urban school students (Porozovs, Mikelsone, Voita, 2015). Information and communication technologies (ICT) have become a significant factor, which influence lifestyle, education and everyday life of people (Facer, 2011). Effective ICT implementation can promote constructive learning environment, which facilitate creative and critical thinking of students (Al Harbi, 2014). Wide using of ICT can lead to different effects. Results of research have shown that boys who use computers for doing homework, "surfing" the Internet, and communicating with others engage in more social-physical activities than others but boys who use computers to play games tend to be more social-behaviourally inactive (Ho, Lee, 2001).

In order to maintain health level of young people and reach high learning outcomes it necessary to understand lifestyle peculiarities and problems of different age students. Information about lifestyle peculiarities could give ability to work out recommendations and carry out measures for improvement of students' lifestyle and maintain good health level. The aim of the study was to compare lifestyle peculiarities of basic school students and higher educational institution students.

\section{Methodology}

The electronic survey of Riga $2^{\text {nd }}$ Gymnasium $9^{\text {th }}$ grade basic school students (basic school students) and $1^{\text {st }}$ course pedagogical programmes students from University of Latvia (university students) was carried out. Altogether 130 students were questioned (68 university students and 62 basic school students). The survey was worked out in order to clarify and compare the peculiarities of lifestyle of different age students. The research was carried out on the $2017^{\text {th }}$ year.

SPSS statistical data processing program was used for statistical analysis. Mann-Whitney U test was used for data analysis. The research question was: are there differences in lifestyle of basic school and university students?

\section{Results and Discussion}

The results of the survey showed that time which students spend on a computer is rather different for different students. In general university students spend more time on a computer than basic school students (Figure 1).

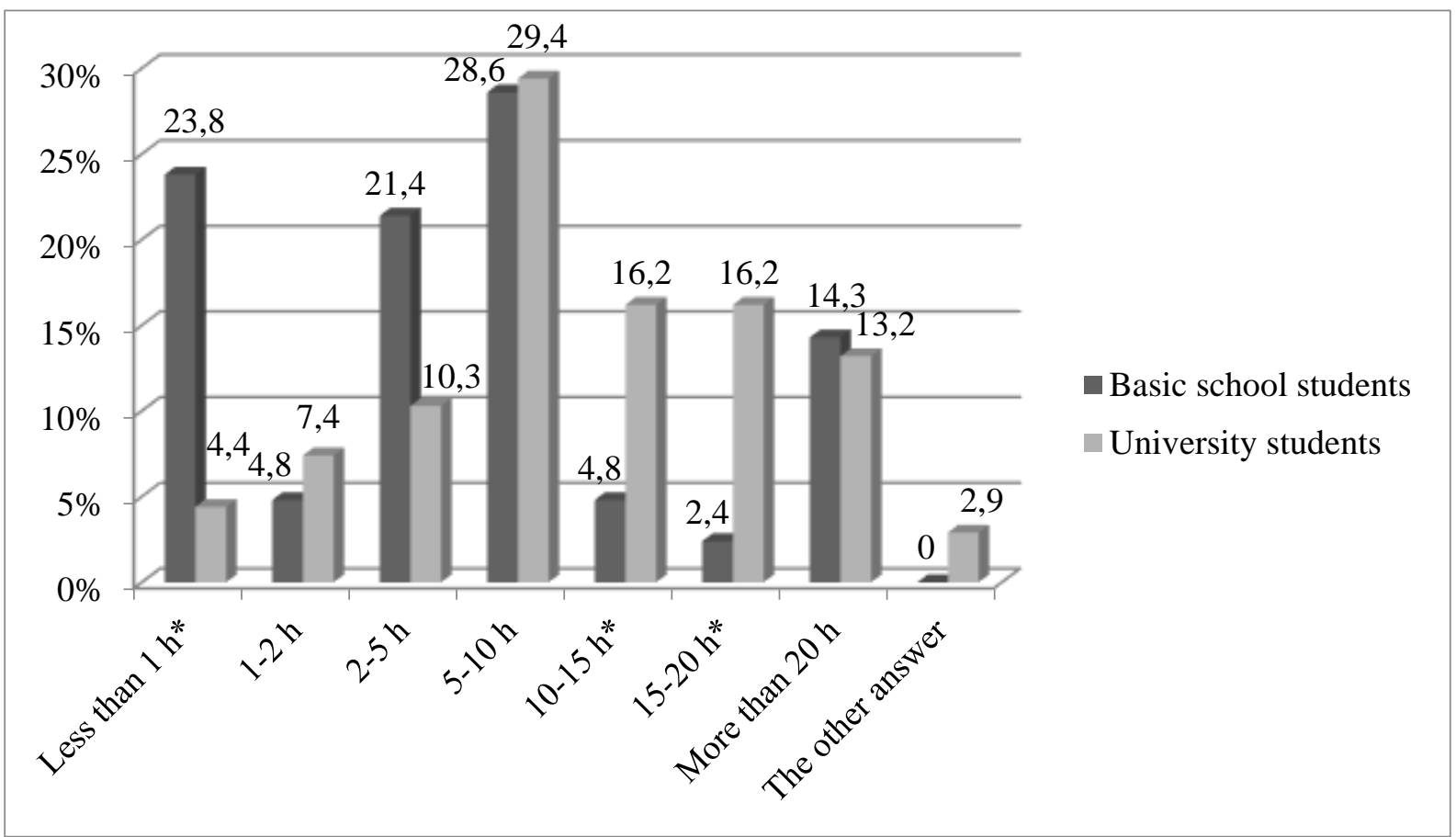

Figure 1. The time which students spend on a computer

(in $\%$ from the number of respondents) $(* \mathrm{p}<0,01)$.

Twenty-three-point eight percent of basic school students spend less than 1 hour on a computer during week. Only four-point four percent of university students spend less than one hour during week on a computer (the difference is statistically significant $p<0,01$ ). The majority of basic school students spend 2-5 or 5-10 hours 
during week on a computer, but the majority of university students spend $5-10,10-15$ or 15-20 hours during week on a computer. At the same time in both groups there are students who spend more than 20 hours during week on a computer (14,3\% of basic school students and $13,2 \%$ of university students).

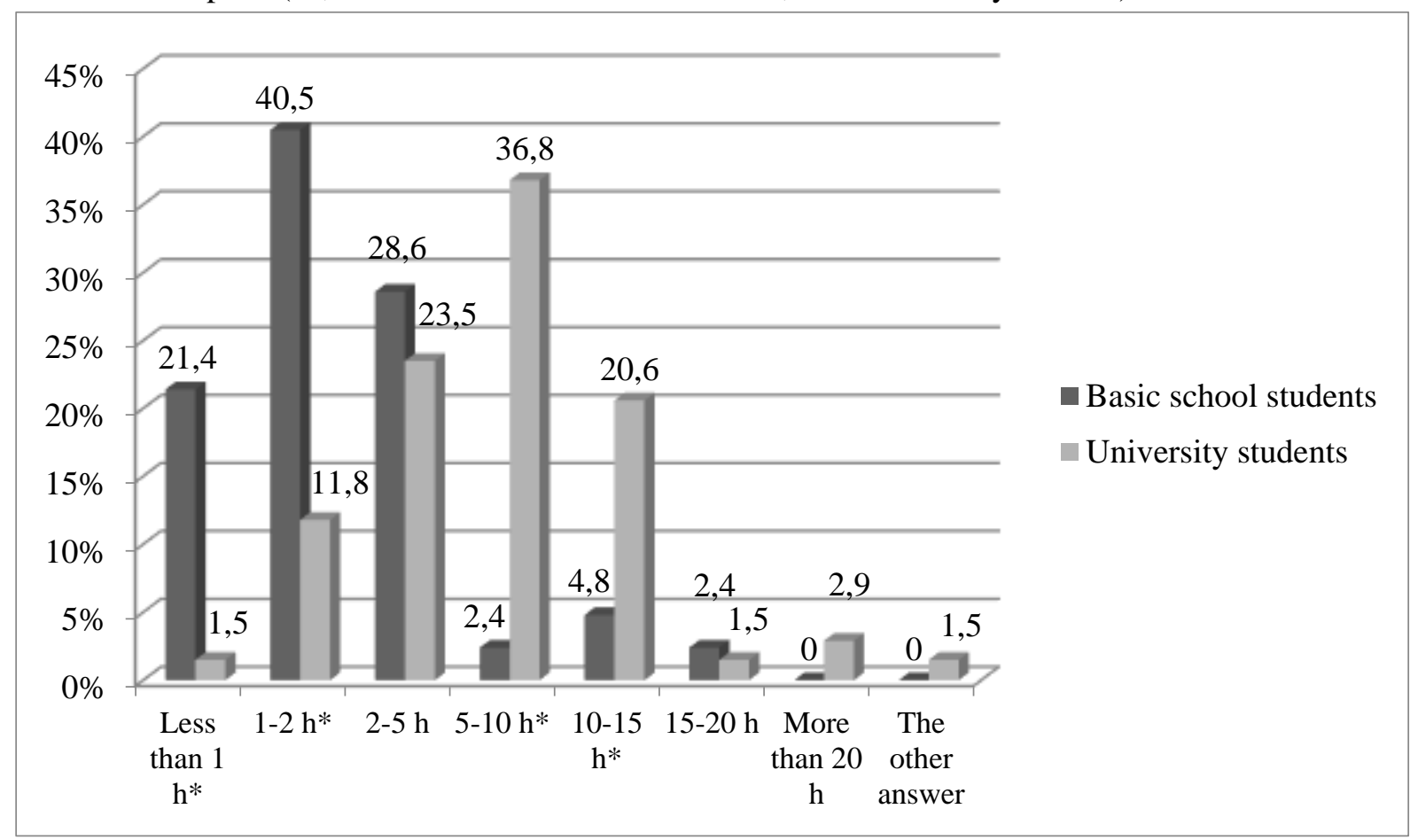

Figure 2. The time which students spend on a computer with activities connected with studies (in $\%$ from the number of respondents) $(* \mathrm{p}<0,01)$.

University students spend more time on a computer on activities connected with studies in comparison with basic school students (Figure 2).

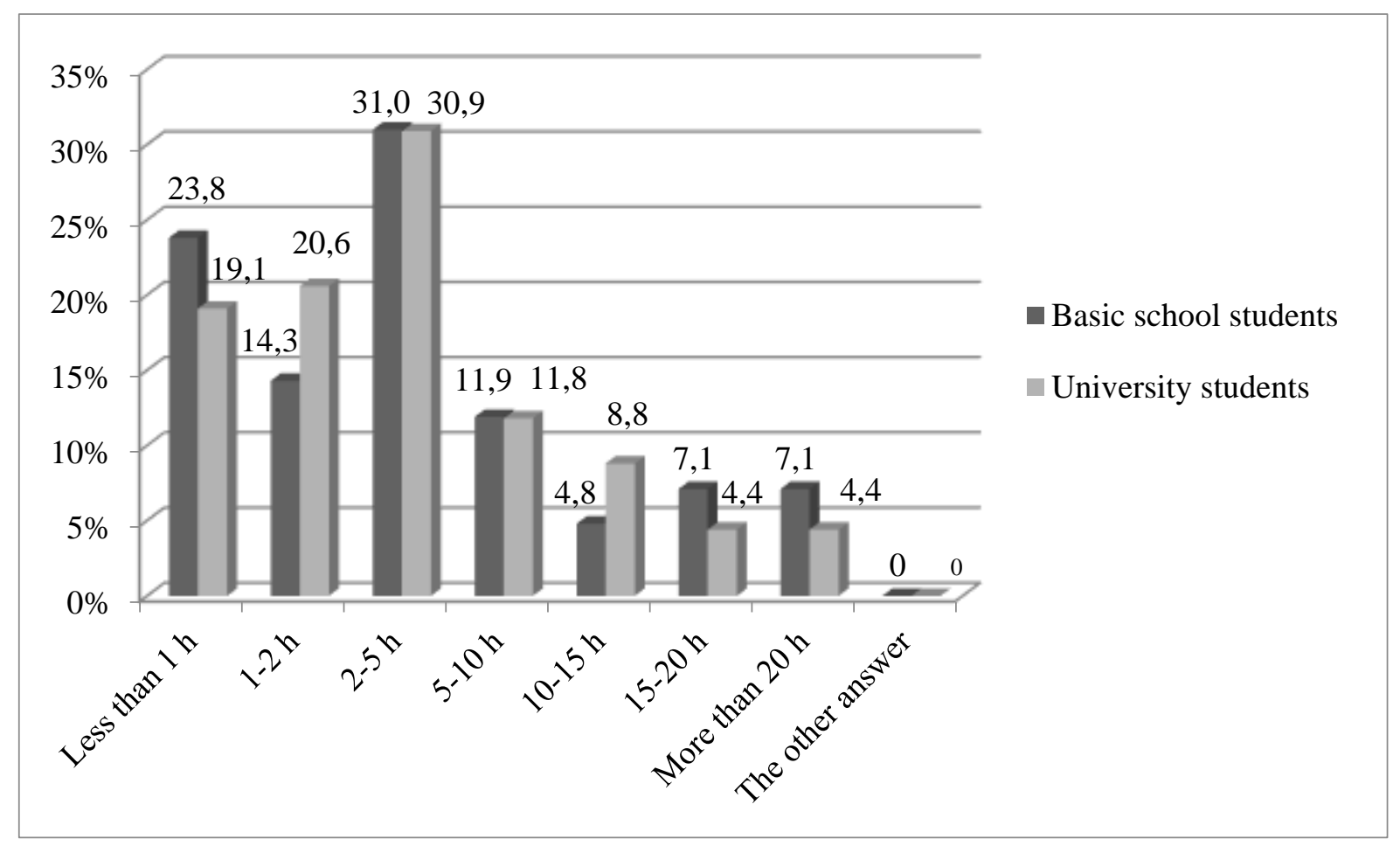

Figure 3. The time, which students spend on a computer with activities not connected with studies (in \% from the number of respondents).

Twenty-one-point four percent of basic school students spend less than 1 hour during week on a computer, but only one-point five percent of university students spend less than 1 hour during week 
on a computer with activities connected with studies (the difference is statistically significant $p<0,01$ ). The majority of basic school students spend 1-2 or 2-5 hours, but the majority of university students spend 5-10 or 10-15 hours on a computer with activities connected with studies.

There are no statistically significant differences between student groups in the time, which students spend on a computer with activities not connected with studies (Figure 3). The majority of students spend 2-5 hours during week on a computer with activities not connected with studies (31\% of basic school students and $30,9 \%$ of university students).

Data of literature suggest that higher school performance significantly positively correlated with internet use for study but negatively correlated with internet use for general purpose. Academic use of the internet could be a means of achieving good school performance (Kim et al., 2017). These data correlate with results of current investigation - university students spend more time on computer in comparison with secondary school students in order to fulfil tasks connected with education.

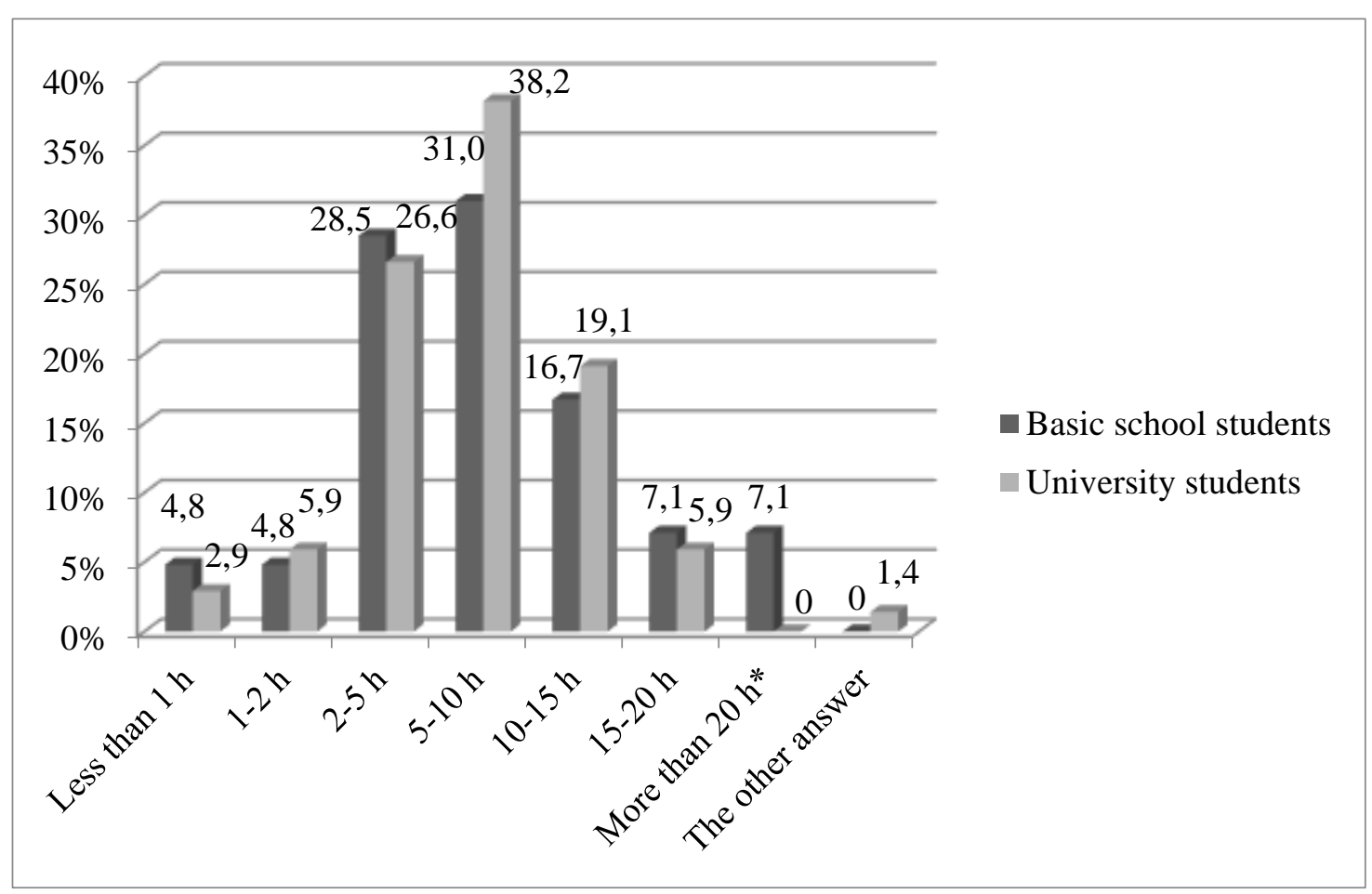

Figure 4. The time which students spend doing study home works (in $\%$ from the number of respondents) $(* \mathrm{p}<0,01)$.

The time which students spend doing study home works is different for different students (Figure 4). The majority of basic school students as well as university students spend 2-5 hours during week $(28,5 \%$ of basic school students and 26,6\% of university students) or 5-10 hours during week (31\% of basic school students and $38,2 \%$ of university students) doing study home works. There are more basic school students $(7,1 \%)$ in comparison with university students $(0 \%)$ who spend more than 20 hours during week doing study home works. Obviously, some of basic school students are very interested in obtaining new knowledge and development of their career.

The physical activities of basic school students are higher than the physical activities of university students (Figure 5). Nineteen-point four percent of university students' physical activities are very low - they spend less than 1 hour during week engaging in physical activities, only four-point eight percent of basic school students have so low physical activity. Twenty-eight-point six percent of basic school students spend 5-10 hours during week participating in physical activities, but only nine-point seven percent of university students have such level of physical activities (the difference is statistically significant $\mathrm{p}<0,01)$. Perhaps university students are not so interested in sports or they have less time to go into sports.

The results of current investigation correlate with the results of J. Marks and colleagues, which suggest that transitioning from primary to secondary school has negative impact on children's physical activity 
and sedentary behaviour (Marks et al., 2015). Perhaps, it may connect with changes in school environment, changes of students' interests and increase of duties and tasks.

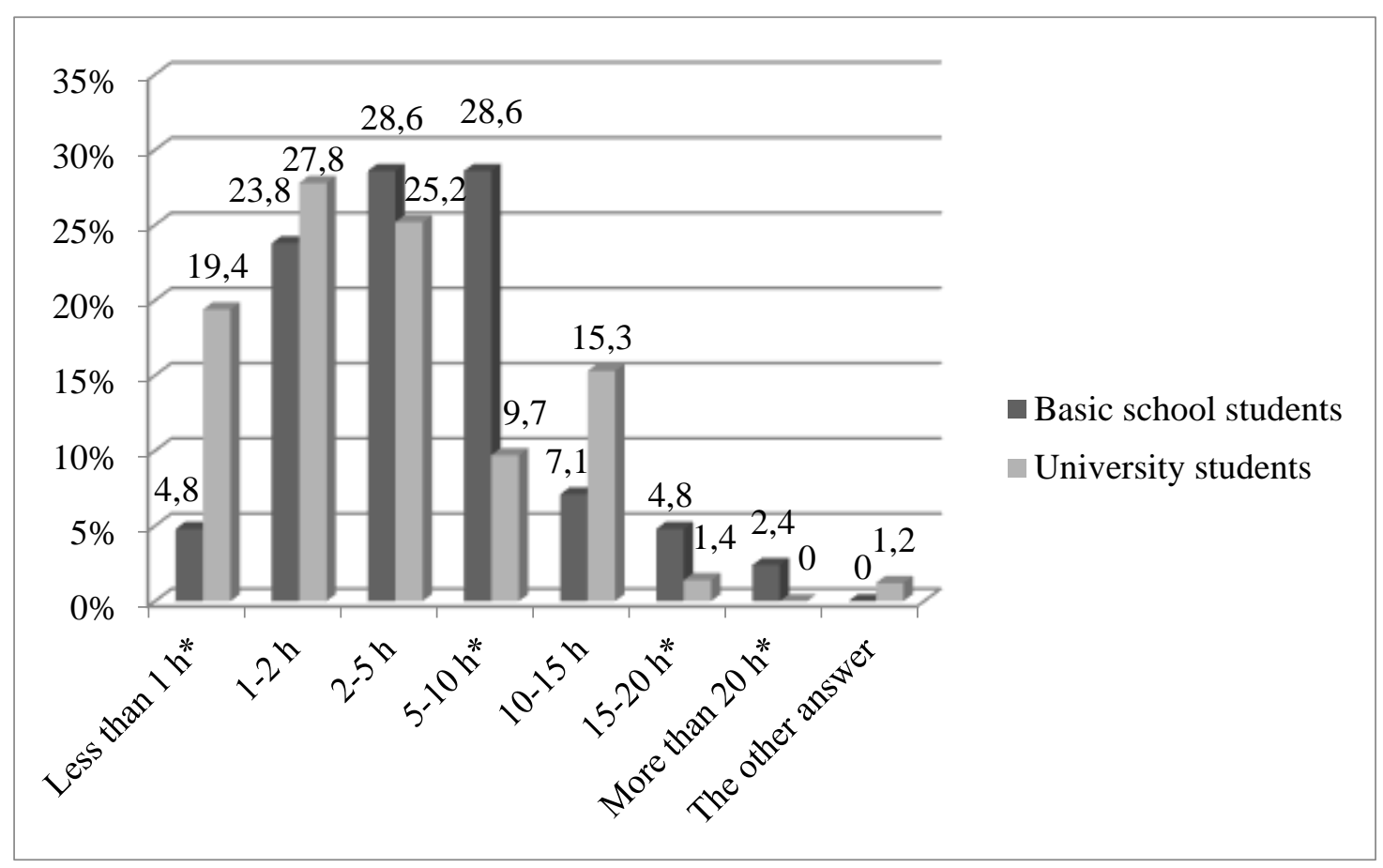

Figure 5. The time which students spend participating in physical activities

(in $\%$ from the number of respondents) $\left({ }^{*} \mathrm{p}<0,01\right)$.

The time which students spend watching TV is not greatly different between both group students (Table 1). Thirty-eight-point one percent of basic school students and thirty-six-point eight percent of university students watch TV less than 1 hour during week. These results show that many students find more important or more interesting activities than watching TV. Only few students watch TV 10-15 hours during week ( $4,8 \%$ of basic school students and $4,4 \%$ of university students) or more.

Table 1

The time which students spend watching TV, reading literature and engaging in music (in \% from the number of respondents)

\begin{tabular}{|c|c|c|c|c|c|c|}
\hline \multirow{2}{*}{$\begin{array}{c}\text { Time during } \\
\text { week }\end{array}$} & \multicolumn{2}{|c|}{ Watching TV } & \multicolumn{2}{c|}{ Reading literature } & \multicolumn{2}{c|}{ Dealing with music } \\
\cline { 2 - 7 } & $\begin{array}{c}\text { Basic } \\
\text { school } \\
\text { students }\end{array}$ & $\begin{array}{c}\text { University } \\
\text { students }\end{array}$ & $\begin{array}{c}\text { Basic } \\
\text { school } \\
\text { students }\end{array}$ & $\begin{array}{c}\text { University } \\
\text { students }\end{array}$ & $\begin{array}{c}\text { Basic } \\
\text { school } \\
\text { students }\end{array}$ & $\begin{array}{c}\text { University } \\
\text { students }\end{array}$ \\
\hline Less than 1 hour & 38,1 & 36,8 & 40,5 & 35,3 & 31,0 & 30,9 \\
\hline 1-2 hours & 19,0 & 19,1 & 23,8 & 22,1 & 21,4 & 22,1 \\
\hline 2-5 hours & 29,0 & 20,6 & 26,2 & 29,4 & 14,3 & 13,2 \\
\hline 5-10 hours & 7,4 & 10,3 & 2,4 & 2,9 & 10,5 & 14,6 \\
\hline 10-15 hours & 4,8 & 4,4 & 0 & 1,5 & 3,8 & 2,9 \\
\hline 15-20 hours & 0 & 1,5 & 0 & 0 & 7,1 & 4,5 \\
\hline $\begin{array}{c}\text { More than 20 } \\
\text { hours }\end{array}$ & 0 & 1,5 & 0 & 1,5 & 4,0 & 5,9 \\
\hline The other answer & 4,8 & 5,9 & 7,1 & 7,4 & 7,9 & 5,9 \\
\hline
\end{tabular}

The majority of students are not spending much time for reading literature (Table 1). Forty-point five percent of basic school students and thirty-five-point three percent of university students read literature less than 1 hour during week. Only two-point four percent of basic school students and two-point nine percent of university students read literature 5-10 hours during week. 
The majority of students are not much dealing with music as well $(31,0 \%$ of basic school students and $30,9 \%$ of university students are dealing with music less than 1 hour during week) (Table 1). At the same time there are students between both groups who are dealing with music 15-20 hours during week and even more than 20 hours during week $(4,0 \%$ of basic school students and 5,9\% of university students). Perhaps these students closely connect their profession and lifestyle with music.

The time, which students spend during sleep is longer for university students in comparison with basic school students (Figure 6). Twenty-eight-point six percent of basic school students sleep less than 6 hours during night, but only five-point nine percent of university students sleep less than 6 hours during night. Seventeen-point six percent of university students sleep 8-9 hours during night, but only twopoint four percent of basic school students sleep 8-9 hours during night.

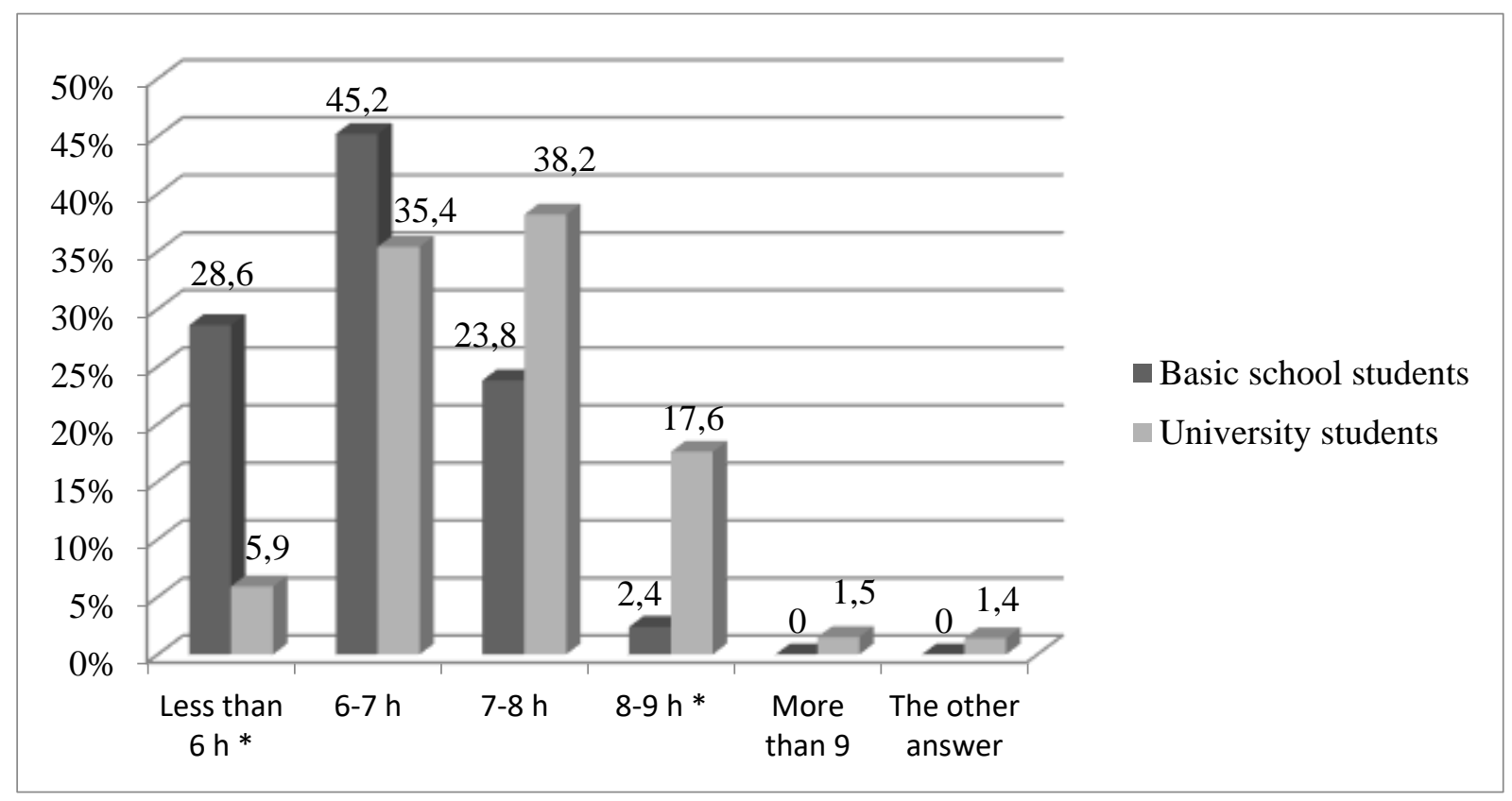

Figure 6 . The time, which students spend during sleep in night

(in $\%$ from the number of respondents) $(* \mathrm{p}<0,01)$.

Obviously, the lifestyle of basic school students is more active and perhaps they less connect their health level with enough sleep during night. It is well known, that adequate time spend in sleep is very important for maintaining health, but it seems that for many of basic school students it is too short.

\section{Conclusions}

- University students spend more time on a computer than basic school students. University students spend more time on a computer on activities connected with studies but the time, which students spend on a computer with activities not connected with studies do not greatly differ between both group students.

- The time which students spend doing study home works in general do not greatly differ between basic school students and university students but there are more basic school students $(7,1 \%)$ in comparison with university students $(0 \%)$ who spend more than 20 hours during week doing study home works.

- The physical activity of basic school students is higher than the physical activity of university students. For many university students' physical activities are very low. Nineteen-point four percent of university students spend less than 1 hour during week engaging in physical activities. It is recommended to involve students in different physical activities, such as sports, dance and hiking in order to reduce sedentary lifestyle possibilities.

- The time which students spend watching TV, reading literature and dealing with music is not greatly different between basic school students and university students. The majority of both group students spend less than 1 hour during week or 1-2 hour during week for these activities but in both groups, there are students who spend more than 20 hours during week $(4,0 \%$ of basic school students and 5,9\% of university students) dealing with music. 
- The time, which students spend during sleep, is longer for university students in comparison with basic school students. It is too short for many basic school students. Twenty-eight-point six percent of basic school students sleep less than 6 hours during night. It is recommended for these students to plan daily activities in such way, that there is enough time for sleep during night.

\section{Bibliography}

1. Al Harbi H.E. (2014). Towards Successful Implementation of ICT in Education. The 2014 WEI International Academic Conference Proceedings. Vienna: The West East Institute, 33-45. Retrieved from https://www.westeastinstitute.com/wp-content/uploads/2014/05/Hanaa-Eid-Alharbi-Full-Paper.pdf

2. Facer K. (2011). Learning Futures. Education, Technology and Social Change. New York, London: Routledge. Retrieved from http://www.bpums.ac.ir/UploadedFiles/CourseFiles/[Keri_Facer]_Learning_Futures_Education, Technolo_f9e20225.pdf

3. Guthold R., Cowan M.J., Autenrieth C.S., Kann L., Riley L.M. (2010). Physical activity and sedentary behavior among schoolchildren: a 34-country comparison. The Journal of Pediatrics, 157(1), 43-49. Retrieved from https://www.ncbi.nlm.nih.gov/pubmed/20304415

4. Ho S.M., Lee T.M. (2001). Computer usage and its relationship with adolescent lifestyle in Hong Kong. The Journal of Adolescent Health, 29(4), 258-266. Retrieved from https://www.ncbi.nlm.nih.gov/pubmed/11587909

5. Kim S.Y., Kim M.S., Park B., Kim J.H., Choi H.G. (2017). The associations between internet use time and school performance among Korean adolescents differ according to the purpose of internet use. PLOS ONE, 12(4), Article Number: e0174878. Retrieved from http://journals.plos.org/plosone/article?id=10.1371/journal.pone.0174878

6. Marks J., Barnett L.M., Strugnell C., Allender S. (2015). Changing from primary to secondary school highlights opportunities for school environment interventions aiming to increase physical activity and reduce sedentary behaviour: a longitudinal cohort study. The International Journal of Behavioral Nutrition and Physical Activity, 8(5), 12-59. Retrieved from https://www.ncbi.nlm.nih.gov/pubmed/25952318

7. Michaud I., Chaput J.P., O'Loughlin J., Tremblay A., Mathieu M.E. (2015). Long duration of stressful homework as a potential obesogenic factor in children: a QUALITY study. Obesity (Silver Spring), 23(4), 815-822. Retrieved from https://www.ncbi.nlm.nih.gov/pubmed/25755164

8. Pestana L., Duarte J., Coutinho E. (2015). Determinants of School Performance in Adolescents. In L.G. Chova, A.L. Martinez, I.C. Torres (Eds.), Proceedings of the Conference International Technology, Education and Development (INTED), 9. Madrid, Spain: IATED Academy, 6918-6925. Retrieved from https://library.iated.org/view/PESTANA2015DET

9. Porozovs J., Mikelsone Z., Voita D. (2015). 9.klases skolenu dzivesveida ipatnibas un macibu motivacija Latvijas pilsetas un lauku rajonos (Peculiarities of Lifestyle and Learning Motivation of 9th Grade Students in Cities and Rural Area Schools of Latvia). In V. Lubkina (Ed.), Proceedings of the International Scientific Conference Society, Integration, Education, 2. Rezekne: RA Izdevnieciba, 144-154. Retrieved from http://journals.ru.lv/index.php/SIE/article/view/447/451. (in Latvian)

10. Regis M.F., de Oliveira L.M.F.T., dos Santos A.R., Leonidio A.D.C.R., Diniz P.R.B., de Freitas C.M.S.M. (2016). Urban versus rural lifestyle in adolescents: associations between environment, physical activity levels and sedentary behavior. Einstein-Sao Paulo, 14(4), 461-467. retrieved from http://www.scielo.br/scielo.php?pid=S1679-45082016000400461\&script=sci abstract

11. Ren H., Zhou Z., Liu W.K., Wang X., Yin Z. (2017). Excessive homework, inadequate sleep, physical inactivity and screen viewing time are major contributors to high paediatric obesity. Acta Paediatrica, 106(1), 120-127. Retrieved from https://www.ncbi.nlm.nih.gov/pubmed/27759894

12. Viera T.P.F., Alves N.J.C.C., Dias C.S.L., de Fonesca A.M.L.F.M. (2015). Regional asymmetries. What are the differences in lifestyles and life satisfaction among adolescents? A study of students of the 3rd cycle of basic education in Portugal. Ciencia and Saude Coletiva, 20 (1), 17-29. 